\title{
Development of ecosystem health indicators for a municipality in southern Ontario, Canada
}

\author{
H. Shear ${ }^{1}$, S. Da Silva ${ }^{1} \&$ C. Toth $^{2}$ \\ ${ }^{I}$ Department of Geography, University of Toronto Mississauga, Canada \\ ${ }^{2}$ Environmental Policy, Town of Oakville, Canada
}

\begin{abstract}
In December 2005, an Environmental Strategic Plan (ESP) was adopted by the Town of Oakville Council. A priority for action in the ESP was the development of a set of environmental health indicators by which to measure the state of Oakville's environment. These indicators will form the basis of a regular "State of the Environment" report for Oakville. The scope of the ESP is broad, in that it encompasses natural resources (biodiversity), waste management, transportation, heritage issues, safety, economic development, and human health and wellbeing. While the ESP is not a sustainability plan per se, it will be integrated, along with other Town master plans, into a Town sustainability plan. The indicators for the ESP would comprise part of the indicator suite within an overall sustainability model. This paper describes the process that the Town of Oakville undertook to develop a first set of environmental health indicators.
\end{abstract}

Keywords: indicators, municipality, state of environment, reporting, Oakville.

\section{Introduction}

The Town of Oakville is a community of approximately 165,000 on the north shore of Lake Ontario (Figure 1). In early 2003, the Town of Oakville made a commitment to develop an Environmental Strategic Plan (ESP). The Town and its citizens were clear that the ESP should develop a vision, outline goals, and establish measurable targets and the means to achieve environmental protection and improvements throughout the entire geographic area of Oakville. The development of the Plan was an opportunity for residents, commercial interests, industry, community associations, educators and other community groups to 


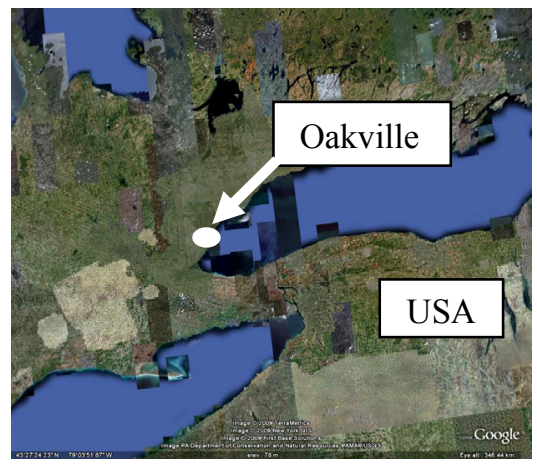

Figure 1: Location of the Town of Oakville, Ontario, Canada.

identify what could be done to protect and improve the environment of the Town of Oakville [1]. This paper outlines the rationale and process that led to the development of a draft set of indicators.

\section{Background}

In the context of this paper, an indicator is a tool that provides information about the state of a geographically defined system - in this case the Town of Oakville. Indicators provide information about conditions at a particular point in time. To be useful, however, indicators need to provide information about trends over time. Furthermore, the indicator needs to have an end point or reference value or bench mark against which one can measure progress, or lack of progress over time. The best way to track trends in the condition of a system over time is through the development and use of a set or "suite" of indicators. By looking at a number of indicators together, one can see whether the system is improving, remaining stationary or is deteriorating [2]. In addition, environmental variables are numerous and sometimes complex; municipalities are limited in resources and it may not be feasible, to measure everything in an ecosystem, hence the demand for indicators.

Through the development and use of a set of indicators, the municipality and citizens of Oakville can:

- assess changes in the state of the local ecosystem and measure progress towards achieving the goals of the ESP;

- understand better how actions can affect the ecosystem, and the types of programs, policies or regulations needed to address the environmental impacts;

- gain a clearer understanding of existing (and emerging) environmental problems and their solutions;

- collect information that will help managers better assess the success of current programs and provide a rationale for future ones, including best management practices (BMP); and

- collect information that will help set priorities for data collection, monitoring and environmental action. 
Using indicators also provides a way of linking the Vision, Goals and Actions for the ESP to specific quantitative targets that will help determine if actions are being successful (Figure 2). This "hierarchy" is best described by using an example of a potential indicator, such as the outdoor air quality in Oakville. For this to be a useful indicator, two things are needed - information on existing air quality for a number of measurable parameters (e.g. particulate matter, ozone) and the standards (end points) that have been established for these parameters for urban areas in Canada. For some indicators such as invasive species, agreeing on the end point will require additional discussion with stakeholders [2].

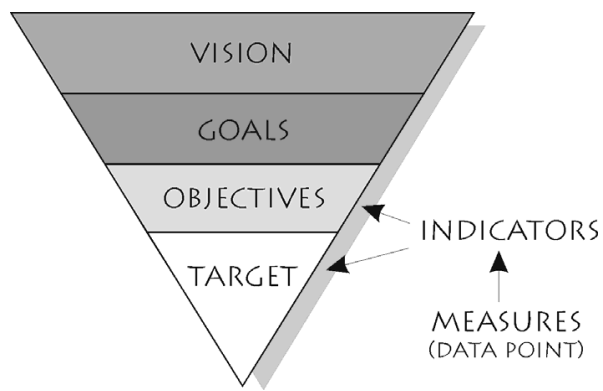

Figure 2: $\quad$ Overview of hierarchy and role of indicators.

\subsection{Selection of a system for types of indicators}

Since 1992, several countries and international organizations have developed a system of indicators suited to their particular geographic setting, spatial scale and economic and environmental context [3-9]. The Organisation of Economic Cooperation and Development [10] developed the Pressure-State-Response Framework (the PSR Framework) in the late 1980s for environmental indicator development. While the indicators used in the Oakville report are not grouped along the lines of the PSR model they will, over time, be used in this context to determine what is the State of Oakville's environment, what are the Pressures on that State that need addressing, and what is being done (Response) about those Pressures.

\subsection{Use existing information}

In developing a set of indicators, the Town was mindful of existing information databases, and built upon those. In a municipal context, there will never be enough resources (money or people) to carry out all the monitoring that is required, so the Town must look at information that is already available, and use it. As indicators were developed, they were referenced to existing or proposed indicators in the literature. From all of the indicators suggested, a subset was selected based on the criteria below, and then further refined, combined or modified to best represent the ecosystem component under consideration [2]. 


\subsection{Indicator selection criteria}

In selecting indicators, the Town developed a list of factors or criteria that were used to select the best set of indicators. These criteria included:

Necessary: Are the indicators necessary to give us the information we need to assess the state of the environment and the success of the ESP?

Sufficient: Will the indicators provide sufficient information to give a picture of the overall health of the environment?

Feasible: Is it feasible (economically and in terms of human resources) to collect information needed for the indicators [2]?

\subsection{The development of targets for an indicator}

An indicator is useful if one can track progress; this means knowing what one wants to achieve by a specific date. Although it is important to have endpoints, a recent study carried out on behalf of the Region of Waterloo noted that the practice of target setting was still in its infancy [11]. Overall, universal standard targets are not yet established among municipalities, and often the target setting process involves making compromises by taking into consideration available scientific information and analysis, political considerations, local concerns, and the sustainability vision of the local community.

\subsection{Limitations of indicators and environmental reporting}

Many parameters can be used to represent water quality or trends in biodiversity, but any one parameter cannot adequately reflect the full scope of water quality or biodiversity. In addition, a particular parameter may be important in one location, but not in another, depending on the ecology of the area.

Data limitations can also contribute to weak environmental reporting in key areas, including water quality, biodiversity, and toxic substances. As a result of budget cutbacks in water quality monitoring, for example, data sets may be incomplete and inconsistent over time, or use different measurement protocols in a time series - all of which are problematic for rigorous indicator development. In addition, municipalities need to rely on other agencies for data, and need to establish formal data sharing / access agreements.

Furthermore, SOE reporting using environmental indicators may inform decision-makers that the environmental condition and trend is "mixed," meaning that it cannot be determined whether conditions are improving, stable, or are becoming worse. This can lead to confusion, inattention and inaction by policymakers and the public alike. These mixed messages might arise because the environment is complex, the underlying science or the data are limited or incomplete, or the indicators have been developed or interpreted at the wrong level or scale [12].

\section{Methods}

A volunteer Task Force was struck in 2003 to lead the development of the Environmental Strategic Plan (ESP). The Task Force, working with Town 
officials and a consultant, developed a draft ESP by late 2004. The ESP was based on an extensive public opinion survey [13] that had been conducted just prior to the commencement of the Task Force's work. The Survey identified broad areas of interest / concern that the Task Force used to establish Goals for the ESP. Under each Goal, the Task Force identified specific actions to be undertaken and targets met to achieve the goal. A part of the ESP, the Essential Next Steps, identified actions that the Town needed to take immediately upon adoption of the ESP. In 2005, the Town Council adopted the ESP, and established an Environmental Strategic Plan Advisory Committee. One of the Committee's first acts was to begin development of a set of indicators based on the actions identified in the ESP.

The ESP was reviewed in detail using a logical, deductive reasoning approach to draw out major themes, goals and concerns that were highlighted in the ESP's goals, actions and targets. An open-coded and textual approach was used, meaning that there were no pre-existing categories prior to review and the ESP text was analyzed for common themes and indicator potential. Each of the ESP's goals, actions and targets was evaluated using the indicator criteria discussed above to determine if it could potentially be transformed into an environmental or performance indicator. All the actions and targets in the ESP were grouped together based on similarities between them. For example, several actions and targets relate to aquatic habitat, so these were grouped under a heading of 'aquatic habitat' within the Goal of Natural Resources.

From this process, both environmental and performance indicators were developed. Data could be collected over time to populate these indicators to report on trends and changes to the state of Oakville's environment. The performance indicators were designed to highlight the progress achieved or needed to obtain various management and community objectives and targets.

Each proposed indicator was reviewed with the Pressure-State-Response model in mind and written based on a structure developed through the State of the Lakes Ecosystem Conference [14]. Data to populate as many of the indicators as possible were assembled from local (Oakville), Regional (Halton Region) Provincial (Ontario) and some limited National (Canada-wide) data sets.

\section{Results}

One indicator (Outdoor Air Quality) is presented here as an example of the 17 indicators proposed (Table 1). The indicators are grouped into six Focus Areas that are based on the ESP goals.

\subsection{Outdoor air quality}

This indicator will eventually report trends in local air quality and impacts on human health as a result of transported and locally generated air pollutants, using the Air Quality Health Index [16]. Information from the indicator will provide information that will assist in: 
- $\quad$ directing and assessing programs and policies for reducing local causes of air pollution;

- $\quad$ supporting increased transit and alternative transportation use;

- demonstrating the human health impacts of poor air quality;

- reporting requirements to the Provincial government;

- directing and assessing programs and policies related to alternative transportation.

Table 1: $\quad$ Proposed indicators for the Environmental Strategic Plan [15].

\begin{tabular}{|c|c|c|c|c|c|}
\hline $\begin{array}{c}\text { Natural } \\
\text { Resources }\end{array}$ & $\begin{array}{c}\text { Resource } \\
\text { and } \\
\text { Material } \\
\text { Use }\end{array}$ & Transportation & $\begin{array}{l}\text { Healthy } \\
\text { Neighbourhoods }\end{array}$ & $\begin{array}{c}\text { Community } \\
\text { Engagement }\end{array}$ & Best Practices \\
\hline $\begin{array}{l}\text { Green space } \\
\text { and } \\
\text { Biodiversity }\end{array}$ & Solid Waste & $\begin{array}{l}\text { Alternative } \\
\text { Transportation }\end{array}$ & $\begin{array}{l}\text { Noise, Light and } \\
\text { Vibration Pollution }\end{array}$ & $\begin{array}{l}\text { Environmental } \\
\text { Education and } \\
\text { Awareness }\end{array}$ & $\begin{array}{l}\text { Green Building } \\
\text { and } \\
\text { Development }\end{array}$ \\
\hline $\begin{array}{l}\text { Non-Native } \\
\text { Invasive } \\
\text { Species }\end{array}$ & $\begin{array}{l}\text { Water Use } \\
\text { and } \\
\text { Conservation }\end{array}$ & & $\begin{array}{l}\text { Landscaping and } \\
\text { Aesthetics }\end{array}$ & Community Action & $\begin{array}{l}\text { Sustainable } \\
\text { Purchasing }\end{array}$ \\
\hline $\begin{array}{l}\text { Aquatic } \\
\text { Habitat }\end{array}$ & $\begin{array}{l}\text { Energy Use } \\
\text { and } \\
\text { Greenhouse } \\
\text { Gas } \\
\text { Emissions }\end{array}$ & & $\begin{array}{l}\text { Access to Green space } \\
\text { and Recreational Areas }\end{array}$ & & $\begin{array}{l}\text { Sustainable } \\
\text { Fleet }\end{array}$ \\
\hline \multicolumn{6}{|l|}{ Water Quality } \\
\hline $\begin{array}{l}\text { Outdoor Air } \\
\text { Quality }\end{array}$ & & & & & \\
\hline
\end{tabular}

Illnesses such as asthma are associated with air pollution and smog and every year, the environmental and health damages associated with air pollution cost the Ontario economy billions of dollars [17]. Air quality in the Town of Oakville is affected by a number of sources including pollution from other communities in Canada and the United States, and local point source and moving source (vehicular) pollution. There are a number of components that create air pollution and smog, Because of their impact on health, the two that are of greatest concern are ground level ozone $\left(\mathrm{O}_{3}\right)$ and fine particulate matter $\left(\mathrm{PM}_{2.5}\right)$.

\subsubsection{Measures comprising the indicator}

The Canadian Council of Ministers of the Environment has adopted Canada Wide Standards for ozone (65 ppb, 8-hour averaging time) and $\mathrm{PM}_{2.5}\left(30 \mu \mathrm{g} / \mathrm{m}^{3}\right.$, 24-hour averaging time) [18]. Data for Oakville for ozone and $\mathrm{PM}_{2.5}$ are shown in Figures 3 and 4 respectively.

The Air Quality Index (AQI) is a composite index that was developed by the Ontario Ministry of Environment [19]. It is based on measurements of some or all of the six most common pollutants: sulphur dioxide, ground-level ozone, nitrogen dioxide, total reduced sulphur compounds, carbon monoxide and fine 
particulate matter. During any given hour, the pollutant with the highest value becomes the AQI reading. Based on the value, AQI is translated to a category ranging from Very Poor to Very Good. Data for 2007 are shown in Figure 5.

To address some of the shortcomings of the AQI, the Air Quality Health Index (AQHI) is a new national health based index that provides separate recommendations for healthy people and those with breathing problems by using a score derived from a combined reading of ozone at ground level, nitrogen dioxide and particulate matter. These three pollutants were selected based on their impacts to human health [16].

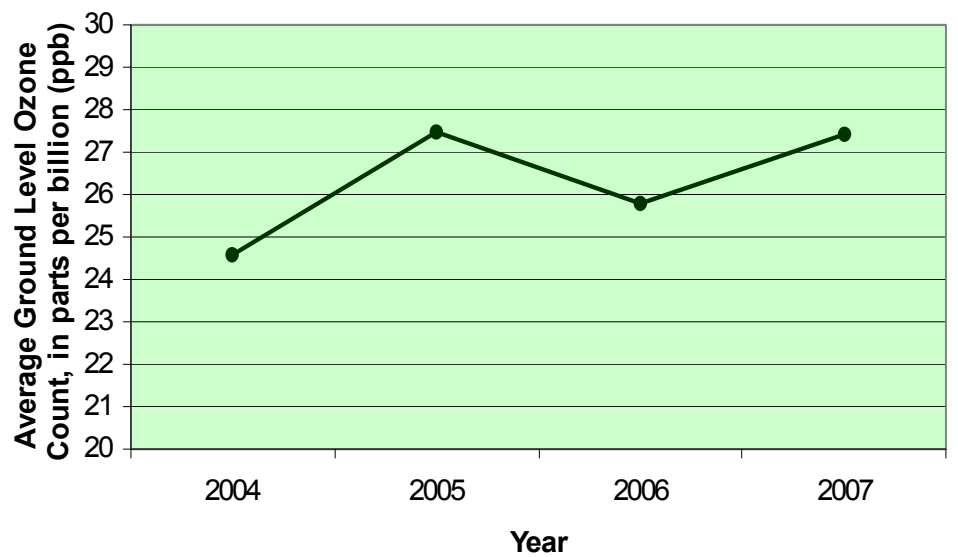

Figure 3: $\quad$ Annual average ground level ozone levels.

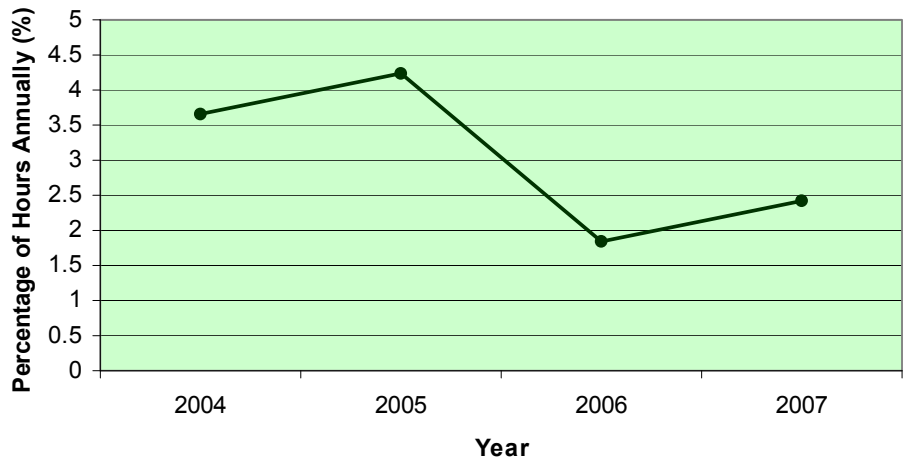

Figure 4: Annual percentage of hours exceeding $30 \mu \mathrm{g} / \mathrm{m}^{3} \mathrm{PM}_{2.5}$.

The Ontario Ministry of the Environment has estimated that transboundary air pollution accounts for more Ontario deaths attributable to air pollution $(56 \%)$ than air pollution generated within Ontario (44\%) [20]. The Ontario Medical Association has estimated the number of premature deaths in Ontario due to smog (Figure 6) [21]. Unfortunately, the uncertainty surrounding exposure and risk limits our ability to calculate reliable local estimates of the potential impact of air pollution on mortality. 


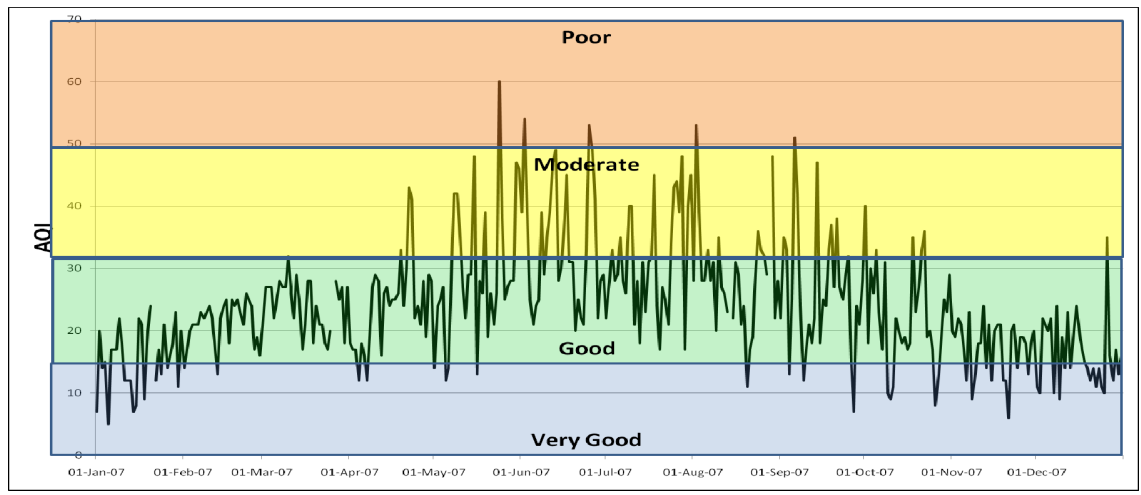

Figure 5: $\quad$ Air Quality Index for Oakville, 2007.

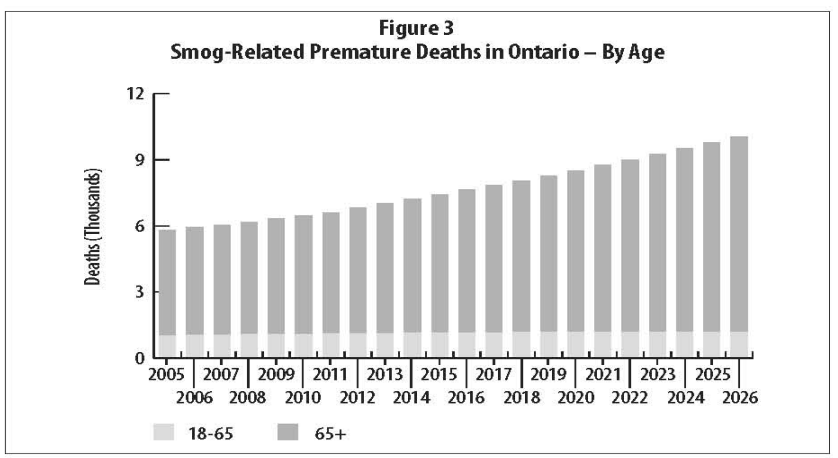

Figure 6: $\quad$ Smog related premature deaths in Ontario by age.

\subsubsection{Limitations}

Air pollution does not have boundaries, thus, it is difficult to accurately track the impact of local air quality improvement initiatives. Emissions and poor air quality from other Canadian sources and the United States, impact the Town of Oakville's air quality. Differences in weather from one year to the next complicate analysis of ambient trends. Ozone and fine particulate matter can be elevated during hot summers and drought conditions result in higher particulate matter levels due to increased fugitive dust emissions.

In urban centres, pollutant concentrations increase along busy streets, particularly during peak hours of traffic. The air that people actually breathe at street-level can differ significantly from the ambient air upon which AQI reports are based. Another shortcoming of the AQI is that it does not consider the potential cumulative or synergistic effects of different pollutants present in the air at the same time. The AQI assesses each pollutant independently, and hourly AQI ratings are based solely on the pollutant with the highest rating during that time. 


\section{Discussion}

The process of indicator identification and development took just over one year (2007-2008). The various drafts of indicators were reviewed and approved by the ESP Advisory Committee. In early 2009, a State of Environment Report (SOER) for Oakville was released. The Report was based on the indicator set described in this paper. This report will be updated and issued annually. Every five years, starting in 2010, the Environmental Strategic Plan will undergo a comprehensive review to determine the level and success of implementation of the Plan. Parallel to this ESP review, the SOER will also undergo a review to determine whether: the indicators are still appropriate for the SOE report, or should be deleted; there are other indicators that could be used to produce more meaningful results; there are data sources that have not been utilized; there is funding available to allow for data collection and reporting of indicators that previously had not been reported; there are better ways of displaying the information in the reports; and the Town and its citizens are using the information in the SOE reports, and if not, why.

The ESP indicators support and are inter-related with a number of other Town plans and strategies, including: Town of Oakville Strategic Plan 2007 - 2010; Active Transportation Master Plan; North Oakville Secondary Planning; Liveable Oakville - Official Plan; and the Parks, Recreation, Culture and Library Master Plan. The indicators will form the basis of a comprehensive reporting system for all of the Town's environmental initiatives.

The indicators are particularly relevant to the Integrated Community Sustainability Plan [22]. This is required by the Canadian Federal Government by 2010 in order to receive Federal Gasoline Tax (FGT) funds. The Association of Municipalities of Ontario (AMO) in its A Sustainability Planning Toolkit for Municipalities in Ontario [22] notes that "the existence of an Official Plan is sufficient, at a minimum, to meet the requirements of the FGT Agreement. However, the AMO provides guidance regarding what the underlying expectations are of the municipal planning process. ..... a municipality should: "...demonstrate ...that the municipality has: 1) a coordinated approach to community sustainability; 2) reflected and integrated social, cultural, environmental and economic sustainability objectives in community planning; 3) collaborated with other municipalities where appropriate to achieve sustainability objectives; and 4) engaged residents in determining a long-term vision for the municipality."

The impact of the use of the FGT funds will be measured through a set of core indicators measuring a) Cleaner Air; b) Cleaner Water; and c) Lower Greenhouse Gas Emissions. The indicators developed through the ESP will give Oakville a sound footing upon which to build a reporting system for the funds.

The indicator development process outlined in this paper is one that can be used by any municipality with the vision and with adequate institutional capacity to carry out the process. 


\section{References}

[1] Environmental Strategic Plan for the Town of Oakville. 2005. http://www.oakville.ca/Media_Files/BlueprintOakville/ESP_25oct2005.pdf

[2] Shear, H., Stadler-Salt, N., Bertram, P., \& Horvatin, P. The Development and Implementation of Indicators of Ecosystem Health in the Great Lakes Basin. Environmental Monitoring and Assessment 88: 119-152, 2003

[3] United Nations. 2001. Indicators of sustainable development: Framework and methodologies. United Nations, New York. http://www.un.org/esa/ sustdev/csd/csd9_indi_bp3.pdf

[4] United Nations Department of Economic and Social Affairs. 2007. Indicators of sustainable development: guidelines and methodologies. United Nations, New York. http://www.un.org/esa/sustdev/natlinfo/ indicators/guidelines.pdf

[5] United Nations Commission on Sustainable Development. 2001. Work program on indicators of sustainable development. United Nations, New York.

http://daccessdds.un.org/doc/UNDOC/GEN/N00/811/93/PDF/N0081193.p df?OpenElement

[6] Walz, R. 2000. Development of Environmental Indicator Systems: Experiences from Germany. Environmental Management: 26 (6) 613-623.

[7] Organization for Economic Cooperation and Development (OECD). 2001. OECD environmental indicators: towards sustainable development. OECD, Paris, France. 156 pp.

[8] Smith, S. L. 2002. Devising environment and sustainable development indicators for Canada. Corporate Environmental Strategy 9: 305-310.

[9] Tong, C., Wen-Hu, Y., \& Hou, B. 2006. Developing an Environmental Indicator System for Sustainable Development in China: Two Case Studies of Selected Indicators. Environmental Management 38: 688-702.

[10] Organization for Economic Cooperation and Development (OECD). 2003. OECD Environmental Indicators Development, Measurement and Use. Paris, France. 37 pp. http://www.oecd.org/dataoecd/7/47/24993546.pdf

[11] Region of Waterloo (2008). Study on Municipal Target Setting for Sustainability. My Sustainable Canada. September 19, 2008. http://www.region.waterloo.on.ca/web/

[12] Environment Canada. (2005). Current Status, Trends, and Perceptions Regarding Environmental Indicators and State of the Environment Reporting in Canada: Background paper to an Environmental Indicators and State of the Environment Reporting Strategy, 2004-2009. http://www.ec.gc.ca/soer-ree/English/resource_network/bg_paperl_e.cfm

[13] Town of Oakville. 2004. Community Attitude Survey. Unpublished.

[14] Bertram, P. and Stadler-Salt, N., (eds.): 1999, Selection of Indicators for Great Lakes Basin Ecosystem Health, Version 4. U.S. Environmental Protection Agency, Chicago, Illinois U.S.A. and Environment Canada, Burlington, Ontario, Canada. http://www.epa.gov/glnpo/solec/98/ 
[15] Indicators for the Oakville Environmental Strategic Plan (ESP) - Technical Background Report. Town of Oakville. November 22, 2008. Unpublished.

[16] Air Quality Health Index, Province of Ontario. www.weatheroffice.gc.ca/ airquality/pages/onaq-006 e.html

[17] Environmental Commissioner of Ontario (2008). Getting to K(no)w 20072008 Annual Report. October 2008. www.eco.on.ca/eng/uploads/eng_pdfs/ 2008/ar2007.pdf

[18] Canadian Council of Ministers of the Environment. Canada-wide Standards for Particulate Matter and Ozone: Five Year Report: 2000-2005. http://www.ccme.ca/assets/pdf/pm_oz_2000_2005_rpt_e.pdf

[19] Air Quality Index. Ontario Ministry of Environment. www.airquality ontario.com/reports/aqisearch.cfm?stationid $=44017 \&$ Submit $=2007+$ Histor y\&startmonth=all

[20] Ministry of the Environment (2005). Transboundary Air Pollution in Ontario. www.ene.gov.on.ca/envision/techdocs/5158e.pdf

[21] The Ontario Medical Association (OMA). 2006. Smog's excess burden on baby boomers: aging population most vulnerable to smog. https://www.oma.org/Health/smog/index.asp

[22] Association of Municipalities of Ontario. 2008. A Sustainability Planning Toolkit for Municipalities in Ontario. http://www.amo.on.ca/Content/ NavigationMenu/SustainableMunicipalities/FederalGasTax/IntegratedCom munitySustainabilityPlan/default.htm 